\title{
Physiological responses and production of 'Syrah' vines as a function of training systems
}

\author{
Ana Carolina Favero'; Daniel Angelucci de Amorim²; Renata Vieira da Mota²; Claudia \\ Rita de Souza²; Murillo de Albuquerque Regina ${ }^{2 *}$ \\ ${ }^{1}$ UFLA - Programa de Pós-Graduação em Agronomia/Fitotecnia, C.P. 3037 - 37200-000 - Lavras, MG - \\ Brasil. \\ ${ }^{2}$ Núcleo Tecnológico EPAMIG Uva e Vinho, Av. Santa Cruz, 500 - 37780-000 - Caldas, MG - Brasil. \\ *Corresponding author <murillo@epamigcaldas.gov.br>
}

\begin{abstract}
Plant architecture and its interaction with agricultural practices and environmental constraints is determinant for grapevine canopy structure, which is related to carbon assimilation, bud fertility and fruit quality. In this context, this study evaluated the performance of field-grown 'Syrah' grapevines conducted by two management systems: Vertical Shoot Position (VSP) or a modified Geneva Double Curtain (GDC), in Pirapora, state of Minas Gerais, Brazil, during the winters of 2007 and 2008. The evaluations of leaf area, water relations and net $\mathrm{CO}_{2}$ assimilation were made at the end of the ripening period. Yield per vine and per hectare were estimated and mean berry weight and diameter, total soluble solids, $\mathrm{pH}$ and titratable acidity were evaluated during berry ripening. The grapevines trained in VSP had higher water status as compared to GDC, shown by differences in pre-dawn leaf water potential $\left(\Psi_{\mathrm{pd}}\right)$ and stem water potential $\left(\Psi_{\text {stem }}\right)$. However, the $\mathrm{CO}_{2}$ assimilation was similar in both training systems. Fruit exposure was higher in VSP than in GDC, which contributed to increasing berry temperature. At harvest, the berries in GDC reached values near to 23 ${ }^{\circ}$ Brix whereas berries in VSP showed values near $21^{\circ}$ Brix.

Key words: $\mathrm{CO}_{2}$ assimilation, canopy management, water potential, berry temperature, fruit quality
\end{abstract}

\section{Resposta fisiológica e produção do vinhedo de 'Syrah' em função dos sistemas de condução}

\begin{abstract}
RESUMO: A arquitetura da planta e sua interação com práticas agronômicas e variáveis ambientais determinam a estrutura do dossel vegetal, que está envolvida na assimilação de carbono, fertilidade das gemas e qualidade da fruta. Neste contexto, avaliou-se o comportamento de um vinhedo de 'Syrah' conduzido nos sistemas espaldeira (VSP) e Dupla Cortina de Geneva modificado (GDC). As avaliações da superfície foliar primária, relações hídricas e assimilação líquida de carbono foram realizadas no final do período de maturação da uva. Foi feita estimativa da produção por planta e por hectare e avaliados o peso e diâmetro das bagas e teores de sólidos solúveis, $\mathrm{pH}$ e acidez titulável durante o amadurecimento das bagas. As plantas conduzidas em espaldeira apresentaram melhor hidratação, sendo observadas diferenças no potencial hídrico da folha ( $\left.\Psi_{\text {pd }}\right)$ e do caule $\left(\Psi_{\text {stem }}\right)$. A assimilação líquida de $\mathrm{CO}_{2}$ não foi afetada pelos sistemas adotados, e a redução no $\Psi_{\mathrm{pd}}$ e $\Psi_{\text {stem }}^{\mathrm{pd}}$ observada no sistema GDC não alterou a taxa fotossintética. A exposição da fruta foi maior no sistema em espaldeira, o que contribuiu para aumento na temperatura das bagas. Na colheita, as bagas do sistema GDC atingiram valores próximos a $23^{\circ} \mathrm{Brix}$, enquanto no sistema em espaldeira, os valores não passaram de $21^{\circ} \mathrm{Brix}$.

Palavras-chave: assimilação de $\mathrm{CO}_{2}$, manejo de dossel, potencial hídrico, temperatura da baga, qualidade dos frutos
\end{abstract}

\section{Introduction}

Light interception and plant microclimate within canopy, particularly in the fruit zone are among the most important determinants of grape berry composition (Jackson and Lombard, 1993). Sun exposed berries have higher concentration of sugars, organic acids, anthocyanins and aroma compounds (Smart, 1985; Reynolds et al., 2004). However, excessive bunch exposure results in low acid contents and undesirable wine aromas (Jackson and Lombard, 1993). Furthermore, high temperature during berry ripening may inhibit anthocyanin synthesis or increase anthocyanin degradation (Haselgrove et al., 2000). In addition, there is also a relationship between training system, root distribution and leaf surface area, which have impacts on vine water status (Deloire et al., 2004). Grape growth and berry biochemical composition are closely linked to vineyard water status, and to canopy and grape bunch microclimate (Ojeda et al., 2001; Souza et al., 2005a; Santos et al., 2005).

Pirapora, located in the North of the state of Minas Gerais, Brazil, is a traditional region for table grape production. The weather conditions (tropical climate with dry period and a sub-humid condition throughout the year) allow the growth of grapevines of the Vitis vinifera species, including table and wine grapes and it may contribute to expand the winemaking industry in Minas Gerais. The climate conditions also allow the vines to 
produce grapes in two different cycles per year, one cycle from August/September to January/February (the normally cycle adopted in most growing regions of Brazil) called summer cycle, and the other, from February to July, called winter cycle. This last cycle has an advantage upon the summer cycle because the maturation period and harvest coincide with the drier period of the year associated with a larger thermal amplitude. However, there is no information in the literature about the management of vineyards to produce high quality wine under these tropical conditions. In this context, this study evaluated the vine performance of field-grown 'Syrah' grapevines under different training systems. The knowledge of how grapevines respond to different training systems will result in a better control of vegetative growth, yield and must composition, and will also contribute to improve the vineyard management in tropical regions such as Northern Minas Gerais.

\section{Material and Methods}

This study was carried out in an irrigated experimental vineyard located in Pirapora, North of Minas Gerais state, Brazil $\left(17^{\circ} 21^{\prime} \mathrm{S}, 44^{\circ} 55^{\prime} \mathrm{W}\right)$ at an altitude of $505 \mathrm{~m}$. The tropical humid regional climate is classified as $\mathrm{Aw}$ according to Köppen, with a dry season during the winter. The annual average rainfall is $1,200 \mathrm{~mm}$, with 2,695 sunshine hours. The annual averages of maximum temperature and relative humidity are $30.6^{\circ} \mathrm{C}$ and $70.9 \%$, respectively, and the thermal amplitude, based on its monthly averages is $12.7^{\circ} \mathrm{C}$ increasing up to $16.1^{\circ} \mathrm{C}$ during the harvest period (Tonietto et al., 2006).
The evaluations were performed during the ripening period of July of 2007 and 2008, corresponding to the winter growing season, in a $0.2 \mathrm{ha}$ vineyard (480 plants) of 'Syrah' (clone 174) grafted onto 1103 Paulsen rootstock, planted in February 2006. The irrigation management consisted of drip irrigation and the amount of water applied was calculated from the average evapotranpiration $\left(4.00 \mathrm{~mm} \mathrm{day}^{-1}\right)$. From bud burst to the beginning of the maturation period $15 \mathrm{~L} \mathrm{~h}^{-1}$ per plant were applied three times a week and, during the maturation period, the same quantity of water was applied but only once a week, until one week before the harvest.

Production pruning consisted of spur pruned vines with two nodes in length performed in February 2007 and 2008 in lignified shoots formed during the growing season from September 2006 to February 2007 and September 2007 to February 2008. The vines were spaced $2.8 \mathrm{~m}$ between rows and $1.5 \mathrm{~m}$ within rows, at a NorthSouth orientation. Two management systems were tested: Vertical Shoot Position (VSP) and a modified Geneva Double Curtain (GDC) (Figure 1). In the VSP system, the vines were trained on a bilateral Royat Cordon at $1.0 \mathrm{~m}$ aboveground with shoots positioned upwards in three foliage wires (1.0 $\mathrm{m}$ of surface area). In the GDC system, the trunk was $1.9 \mathrm{~m}$ height and the shoots were horizontally divided and trained downwards. The curtains were supported at the top and the shoots were positioned to avoid an excessive light exposure on the fruit zone. Standard cultural practices in the region were applied to both treatments during the growing seasons.
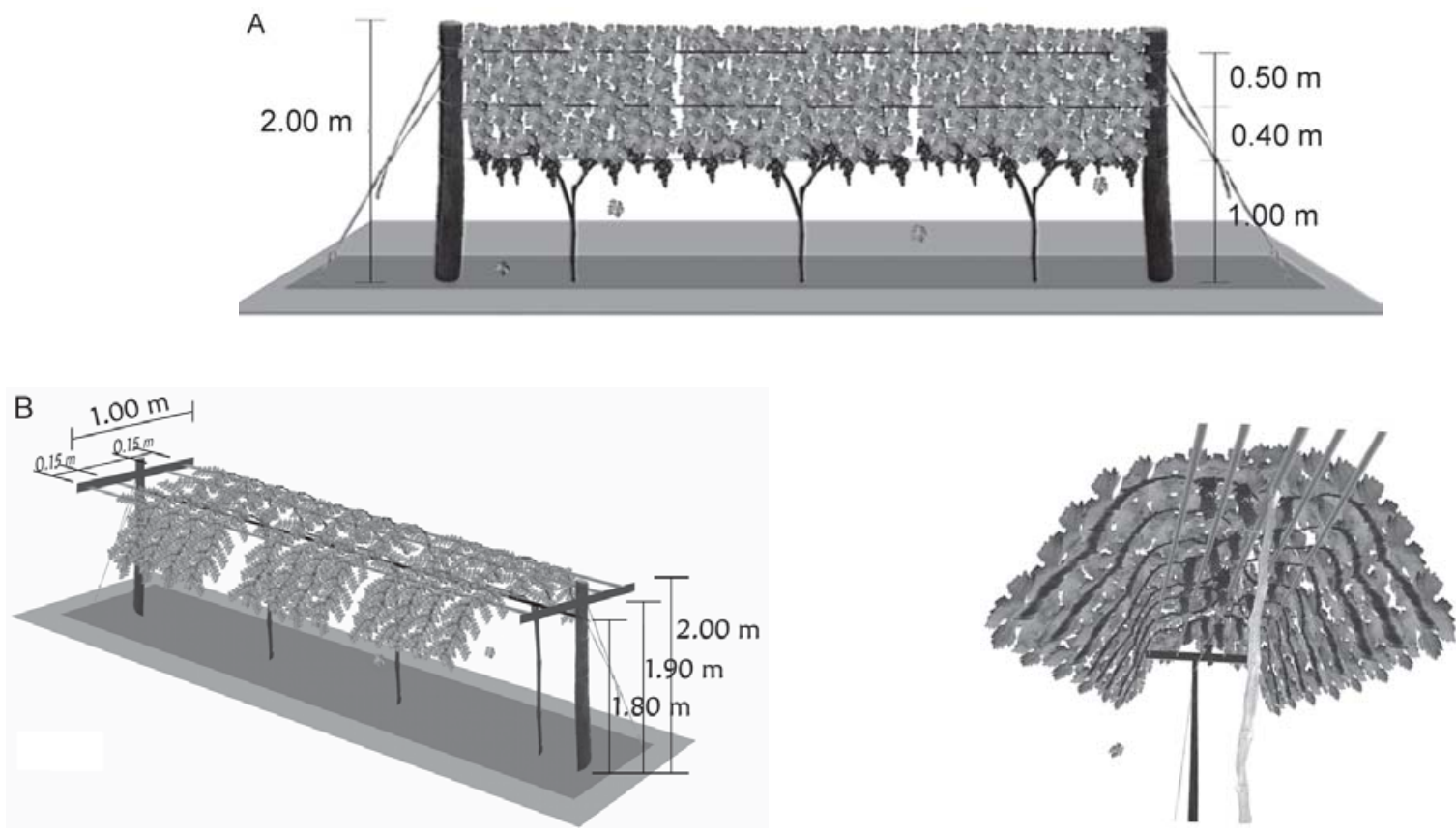

Figure 1 - (A) Vertical shoot positioned (VSP) trellis and (B) Geneva Double Curtain (GDC) trellis, in Pirapora, Minas Gerais, Brazil (winter 2007 and 2008). 
The evaluations of primary leaf surface, water relations and net $\mathrm{CO}_{2}$ assimilation were performed at the end of the ripening period, two weeks before harvest, in a randomized complete design. The primary leaf surface was calculated according to Carbonneau (1976 and 1977, cited by Regina et al., 2000) for ten grapevines per treatment. The vine water status was evaluated in the field through measurements of pre-dawn leaf water potential $\left(\Psi_{\text {pd }}\right)$, midday leaf water potential $\left(\Psi_{\text {md }}\right)$ and stem water potential $\left(\Psi_{\text {stem }}\right)$, measured with a Scholander-type pressure chamber (Soil moisture Equipment Corp., model 3005). Measurements were made on six fully expanded leaves from different vines per treatment. Each removed leaf from the vine was immediately evaluated to avoid water loss. The $\Psi_{\text {pd }}$ was measured before sunrise, the $\Psi_{\text {md }}$ measured at midday, and $\Psi_{\text {stem }}$ was measured between $14 \mathrm{~h} 00$ and $15 \mathrm{~h} 00$. The $\Psi_{\text {stem }}$ was measured according to Choné et al. (2001) on non-transpiring leaves, which had been bagged with both plastic film and aluminum foil 3 hours before measurements.

$\mathrm{CO}_{2}$ assimilation rate (A) was measured in two periods in the morning, at $9 \mathrm{~h} 00$ and $12 \mathrm{~h} 00$ on the same day that water potentials were measured. Six fully expanded and completely exposed leaves situated in the medium portion of the stems were used for the measurements with a portable infrared gas analyzer (model CID 301 PS, working in an open system). The measurements were taken with PAR above $900 \mu \mathrm{mol} \mathrm{m} \mathrm{m}^{-2} \mathrm{~s}^{-1}$.

One day before harvest, forty berries facing west and east ( 20 berries per face) were selected for temperature measurements. Berry temperature was measured at $8 \mathrm{~h} 00$, $10 \mathrm{~h} 00,12 \mathrm{~h} 00,14 \mathrm{~h} 00$ and $16 \mathrm{~h} 00$ with a portable thermometer (Instrutherm, model TE-300). At harvest, the number and weight of bunches were recorded in all vines and also used to estimate yield per vine and per hectare. Mean berry weight was estimated from a sample of 100 berries while the diameters (transversal and longitudinal) were estimated from a sample of 50 berries. A sample of 210 berries divided into three replicates were crushed in a polyethylene bag and filtered. The resulting juice was immediately analyzed for total soluble solids (TSS; ${ }^{\circ} \mathrm{Brix}$ ) with a portable refractometer (ATAGO model PAL-1), and the $\mathrm{pH}$ of undiluted juice of each sample was determined using a $\mathrm{pH}$ meter, and titratable acidity (TA) was determined by titration of diluted juice with $0.1 \mathrm{~mol} \mathrm{~L}^{-1}$ of $\mathrm{NaOH}$ to a phenolphthalein end point and expressed as $\mathrm{g} \mathrm{L}^{-1}$ tartaric acid.
Statistical data analysis was performed by analysis of variance (ANOVA) using the ESTAT software. The statistical differences were detected by the $\mathrm{F}$ test.

\section{Results and Discussion}

Grapevines trained in VSP were in a higher water status than in the GDC as shown by differences in predawn leaf water potential $\left(\Psi_{\mathrm{pd}}\right)$ during both years, and stem water potential $\left(\Psi_{\text {stem }}\right)$ during the 2007 season (Table 1). The $\Psi_{\text {pd }}$ and $\Psi_{\text {stem }}$ have been considered in the literature as good water stress indicators for vines (Deloire et al., 2004). Moreover, the $\Psi_{\text {stem }}$ can be a powerful tool to assess vine water status since it is less affected by shortterm fluctuations induced by stomatal behavior and environmental conditions as compared to $\Psi_{\mathrm{md}}$ (Choné et al., 2001). Despite the differences for $\Psi_{\mathrm{pd}}$ values of the 2007 season, they were above $-0.2 \mathrm{MPa}$ in both management systems, which is in the range considered as absence of water stress, whereas in 2008 season the values were around -0.4 MP, considered as a mild water stress (Deloire et al., 2004). The differences between seasons may be explained by evapotranspiration and by the interval between irrigation and measurements of pre-dawn leaf water potential. The measurements of $\Psi_{\text {pd }}$ in 2008 were made some days after irrigation while in $2007 \mathrm{im}$ mediately after irrigation. Furthermore, the lowest air temperature in $2008\left(28^{\circ} \mathrm{C}\right.$ at $9 \mathrm{hoO}$ and $34^{\circ} \mathrm{C}$ at midday) as compared to $2007\left(30^{\circ} \mathrm{C}\right.$ at $9 \mathrm{~h} 00$ and $36^{\circ} \mathrm{C}$ at midday) and lowest leaf temperature in $2008\left(29^{\circ} \mathrm{C}\right.$ at $9 \mathrm{~h} 00$ and $34^{\circ} \mathrm{C}$ at midday) as compared to $2007\left(35^{\circ} \mathrm{C}\right.$ at $9 \mathrm{~h} 00$ and $39^{\circ} \mathrm{C}$ at midday) also could have contributed to increase the values of $\Psi_{\text {stem }}$ in 2008 .

The decrease in vine water status of the GDC system could be attributed to a greater leaf area resulting in increased water loss observed in this training system (Table 2). Plant water status may be affected by changes in leaf specific hydraulic conductance due to its effect on stomatal conductance (Hubbard et al., 2001; Schultz, 2003; Smart et al., 2006). Furthermore, the greater trunk height in GDC system $(1.90 \mathrm{~m})$ as compared to VSP $(1.0$ $\mathrm{m})$ and also the differences in branch orientation could have contributed to hinder water transport to the grapevine canopy. Schubert et al. (1999) showed that shoot hydraulic conductivity is negatively affected by downward branch orientation in contrast with upward growing

Table 1 - Effect of training system on pre-dawn $\left(\Psi_{\mathrm{pd}}\right)$, midday leaf water potential $\left(\Psi_{\text {md }}\right)$ and stem water potential $\left(\Psi_{\text {stem }}\right)$ of 'Syrah' grapevines in Pirapora, Minas Gerais, Brazil (winter of 2007 and 2008). Values are averages \pm SD. Averages followed by different letters in the same row per season are different $(p<0.05)$.

\begin{tabular}{|c|c|c|c|c|}
\hline \multirow{2}{*}{ Water Potential $(\mathrm{MPa})$} & \multicolumn{2}{|c|}{2007} & \multicolumn{2}{|c|}{2008} \\
\hline & GDC & VSP & GDC & VSP \\
\hline Pre-dawn $\left(\Psi_{p d}\right)$ & $-0.18 \pm 0.04 b$ & $-0.07 \pm 0.04 a$ & $-0.47 \pm 0.02 b$ & $-0.38 \pm 0.02 a$ \\
\hline Midday leaf $\left(\Psi_{\mathrm{md}}\right)$ & $-2.12 \pm 0.12 \mathrm{a}$ & $-1.92 \pm 0.13 a$ & $-1.93 \pm 0.16 a$ & $-1.83 \pm 0.11 \mathrm{a}$ \\
\hline $\operatorname{Stem}\left(\Psi_{\text {stem }}\right)$ & $-1.43 \pm 0.17 b$ & $-1.20 \pm 0.13 a$ & $-0.66 \pm 0.45 a$ & $-0.54 \pm 0.44 a$ \\
\hline
\end{tabular}

$\mathrm{SD}$ - Standard deviation 
branches. Shoot downward orientation induces accumulation of auxin in the apex and this affects the density and the size of the xylem vessels, causing reduction of hydraulic conductivity (Lovisolo at al., 2002).

$\mathrm{CO}_{2}$ assimilation rate (A) of 'Syrah' was not affected by the training systems in both measured periods (Table 2). The reduction in $\Psi_{\text {pd }}$ and $\Psi_{\text {stem }}$ observed in GDC vines did not affect the photosynthesis rate. Although $\Psi_{\text {pd }}$ reached values around $-0.4 \mathrm{MPa}$, considered moderate water stress (Deloire et al., 2004), the photosynthe- sis was unaffected as shown by other authors for grapevine (Souza et al., 2005b) and other crop species (Fereres and Soriano, 2007). The differences between seasons of $\mathrm{CO}$ assimilation rates were probably due to weather conditions (temperatures) during gas exchange measurements, as explained above for results of leaf water potential.

In general, in both growing seasons, the berries of the VSP system had the highest temperatures as compared to GDC in most of the measured time (Figure 2).

Table 2 - Effects of training systems on branch number, yield components, primary leaf surface and $\mathrm{CO}_{2}$ assimilation rate $(A)$ of 'Syrah' grapevines in Pirapora, Minas Gerais, Brazil (winter 2007). The values are averages \pm SD. Averages followed by different letters are different $(p<0.01)$ and $(p<0.05) *$.

\begin{tabular}{|c|c|c|c|c|c|}
\hline & \multicolumn{2}{|c|}{2007} & \multicolumn{2}{|c|}{2008} \\
\hline & & GDC & VSP & GDC & VSP \\
\hline Number of branches per vine & & $15.6 \pm 3.12 \mathrm{a}$ & $11.35 \pm 2.28 b$ & $22.8 \pm 3.29 a$ & $16.70 \pm 3.20 b$ \\
\hline Number of bunches per vine & & $22.1 \pm 3.08 \mathrm{a}$ & $13.85 \pm 4.02 b$ & $37.6 \pm 4.01 \mathrm{a}$ & $26.30 \pm 6.96 b$ \\
\hline Berry weight (g) & & 1.46 & 1.41 & 1.35 & 1.36 \\
\hline Transversal diameter (mm) & & $13.08 \pm 0.63 a$ & $12.36 \pm 0.91 b$ & $12.98 \pm 0.80 a$ & $12.33 \pm 0.79 b$ \\
\hline Longitudinal diameter (mm) & & $14.61 \pm 0.75 a$ & $13.36 \pm 0.81 b$ & $14.18 \pm 1.12 \mathrm{a}$ & $13.25 \pm 0.95 b$ \\
\hline Yield $\left(\mathrm{kg}\right.$ vine $\left.\mathrm{e}^{-1}\right)$ & & $3.17 \pm 0.10 a$ & $1.68 \pm 0.11 b$ & $5.31 \pm 0.57 a$ & $3.57 \pm 0.94 b$ \\
\hline Estimated yield $\left(\mathrm{kg} \mathrm{ha}^{-1}\right)$ & & $7.6 \pm 0.24 a$ & $4.0 \pm 0.27 b$ & $12.6 \pm 1.35 \mathrm{a}$ & $8.5 \pm 2.25 b$ \\
\hline Primary leaf surface $\left(\mathrm{m}^{2}\right)^{*}$ & & $3.9 \pm 2.3 \mathrm{a}$ & $2.11 \pm 0.34 b$ & $4.29 \pm 0.34 a$ & $3.35 \pm 0.85 b$ \\
\hline Leaf area / fruit weight $\left(\mathrm{m}^{2} \mathrm{~kg}^{-1}\right)$ & & $1.00 \pm 0.07 b$ & $1.35 \pm 0.07 a$ & $0.82 \pm 0.17 a$ & $0.95 \pm 0.22 \mathrm{a}$ \\
\hline \multirow{2}{*}{$\mathrm{A}\left(\mu \mathrm{mol} \mathrm{m}{ }^{-2} \mathrm{~s}^{-1}\right) *$} & 9 hoo & $9.38 \pm 1.95 \mathrm{a}$ & $9.69 \pm 1.76 \mathrm{a}$ & $11.48 \pm 3.5 \mathrm{a}$ & $12.23 \pm 0.83 a$ \\
\hline & $12 \mathrm{~h} 00$ & $6.02 \pm 2.7 \mathrm{a}$ & $8.17 \pm 4.24 \mathrm{a}$ & $12.12 \pm 1.93 \mathrm{a}$ & $12.07 \pm 2.55 \mathrm{a}$ \\
\hline
\end{tabular}

SD - Standard deviation
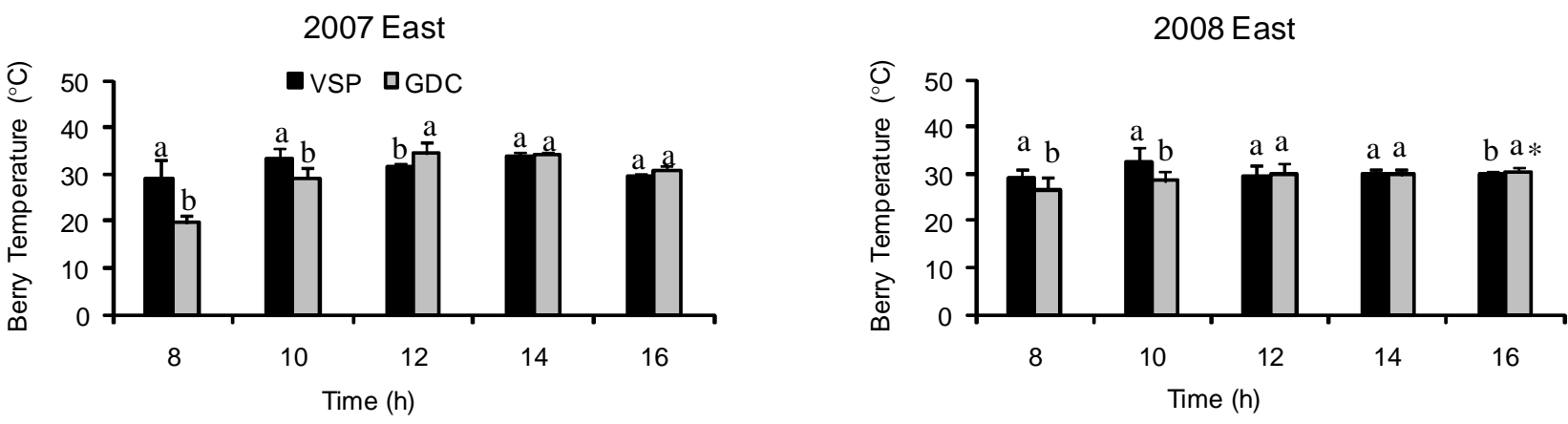

2007 West

2008 West
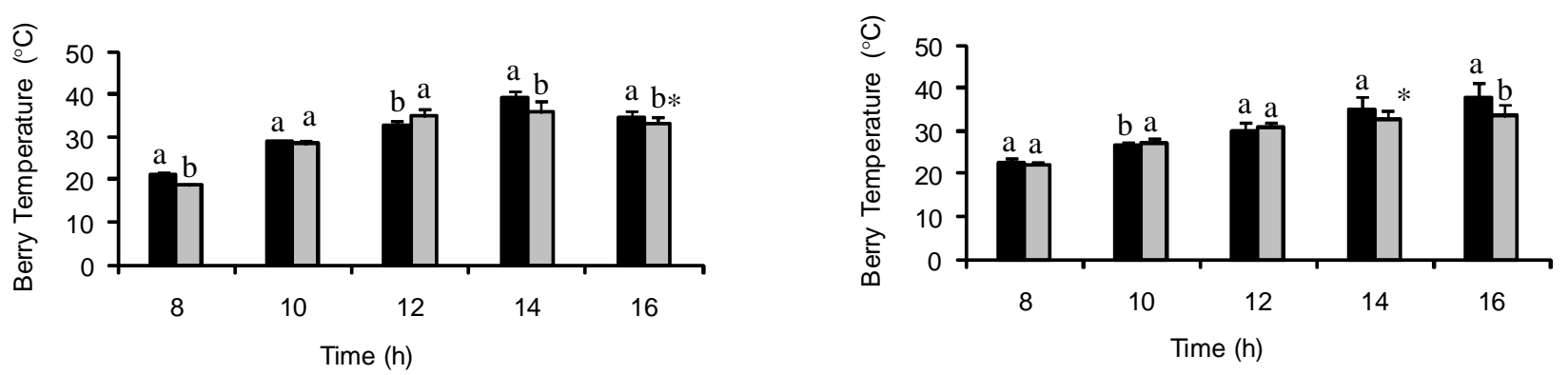

Figure 2 - Effect of training systems on berry temperature measured from 8 h00 to 16 h00 in the East and West faces of the 'Syrah' grapevine. Pirapora, Minas Gerais, Brazil (winter 2007 and 2008). Values are averages \pm SD (Standard Deviation). $p<0.01$, except with * that $p<0.05$. 
The berries of the GDC system only presented highest temperatures at noon in both faces in 2007, and in 2008 at $16 \mathrm{~h} 00$ in the East face and at $10 \mathrm{~h} 00$ in the West face. Fruit exposure was greater in VSP than in GDC, contributing to increase berry temperature. However, in 2007 at midday, the berries in the GDC system had higher temperatures, probably due to the upward position of the leaves of this system that exposed the bunches to higher full solar radiation. Grapevines trained by GDC had greater shoot number and yield than those of the VSP system in both years (Table 2).

Yield was greater for GDC due to greater bunch number, and also due to increased berry diameters (transversal and longitudinal). The greater yield of grapevines for GDC (7.6 ton ha ${ }^{-1}$ in 2007 and 12.6 ton $\mathrm{ha}^{-1}$ in 2008) in contrast to the VSP system (4.0 ton ha ${ }^{-1}$ in 2007
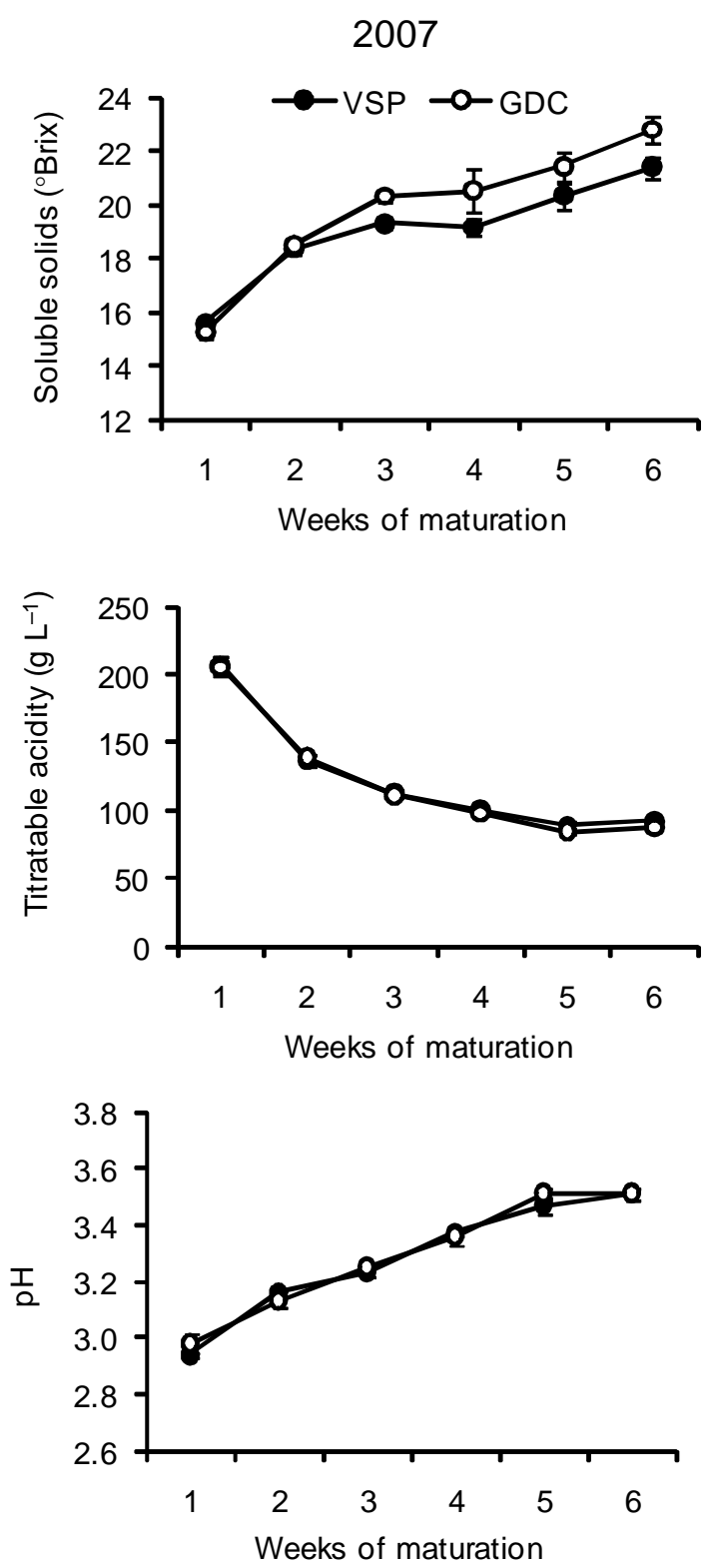

and 8.5 ton $\mathrm{ha}^{-1}$ ) did not negatively affect berry soluble sugar accumulation (Figure 3). At harvest, the berries of GDC reached values near to $23^{\circ}$ Brix and $21^{\circ}$ Brix, in 2007 and 2008, respectively, whereas those for VSP had values around $21^{\circ}$ Brix in both years. The explanations for this result is that most of the sugar load in the berries are derived from plant carbon assimilation (Ruffner et al., 1995; Davis and Robinson, 1996), which is dependent on the total amount of exposed leaf area. Although there were no differences in photosynthetic rates between trellis-training systems (Table 2), the leaf area for GDC was higher as compared to VSP (Table 2) and may have contributed to increase the total carbon assimilation of grapevine trained under the GDC system. In addition, since the type of trellis-training system used has such a dominant influence on the amount of leaf area
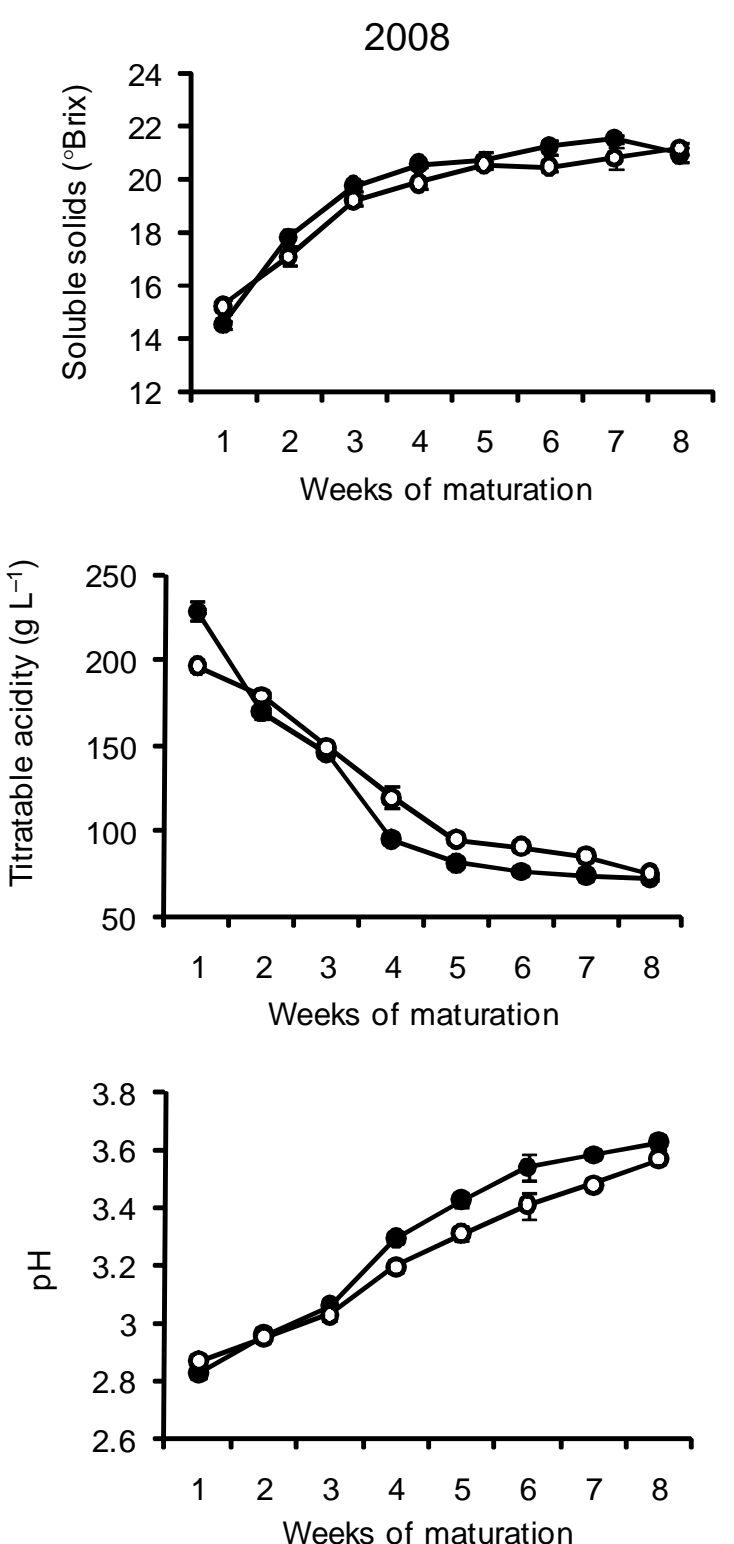

Figure 3 - Effects of training systems on soluble solids, titratable acidity and $\mathrm{pH}$ in must of 'Syrah' grapevines during the ripening periods of 2007 and 2008. The values are averages \pm SD. 
exposure, the optimal leaf area/fruit weight ratio of single- and divided-canopy training systems could also explain the obtained results. In fact, there were significant differences between training systems for the proportion leaf area and fruit weight only in 2007.

For GDC, vines had $1.0 \mathrm{~m}^{2}$ leaf area per $\mathrm{kg}$ fruit, whereas for VSP, this ratio increased to 1.35. The leaf area/fruit weight ratio has been used as a measure of crop load and vine balance for the production of high quality wine. The values found in this study were above the range considered as indicative of well-balanced vines (not over or under cropped) by some authors. Kliewer and Dokoozlian (2005) showed that the leaf area required for maximum level of soluble sugar, berry weight and berry coloration at harvest should be within the range of 0.5 to 0.8 and 0.8 to $1.2 \mathrm{~m}^{2}$ per $\mathrm{kg}$ for GDC and VSP, respectively. However, the ratio below which sugar level starts to decline was also reported by Jackson and Lombard (1993) and Williams (1996) to be between 0.7 and $1.0 \mathrm{~m}^{2}$ per $\mathrm{kg}$. Values given in the literature for the amount of leaf area needed to support a unit weight vary considerably depending on the cultivar, climatic region and method of measurement. In the present study, sugar contents observed for berries of GDC was greater than those of VSP only in the 2007 season, suggesting that GDC vines were better balanced in 2007. Probably, in the under cropped VSP vines there was more competition by photoassimilates between fruits and growing branches (and roots), contributing to decrease sugar concentration (Naor et al., 1997). Furthermore, divided canopy training systems such as GDC have considerably higher percentage of their leaf area at light saturation in contrast to single canopy systems, and, therefore, a lower leaf area/fruit weight ratio for fruit maturation would be expected (Kliewer and Dokoozlian, 2005).

Despite the differences observed in soluble solids only in $2007, \mathrm{pH}$ and titratable acidity did not change between training systems in the two evaluated seasons (Figure 3). Berry composition is affected by exposure to sunlight through temperature and incident radiation. The increased temperature by excessive bunch exposure may produce berries with lower $\mathrm{pH}$ and greater acidity due to malic acid degradation as shown by some authors (Ruffner, 1982; Smart and Robinson, 1991; Jackson and Lombard, 1993). However, in this experiment, the highest berry temperature observed for VSP vines in the morning had no negative impact on total acidity. Similar results were also obtained by Crippen and Morrinson (1986) comparing shaded and sun-exposed fruits.

\section{Acknowledgements}

To thank FAPEMIG, CAPES and CNPq for financial support, the 'Cooperativa Agrícola de Pirapora and Associação dos Usuários do Projeto Pirapora' for providing the grapevines for this study and Laênio Graciano Prado for drawing Figure 1.

\section{References}

Choné, X.; Van Leeuwen, C.; Dubourdieu, D.; Gaudillère, J.P. 2001. Stem water potential is a sensitive indicator of grapevine water status. Annals of Botany 87: 477-483.

Crippen, D.D.; Morrinson, J.C. 1986. Effects of sun exposure on the compositional development of Cabernet Sauvignon berries. American Journal of Enology and Viticulture 37: 235-242.

Davis, C.; Robinson, S.P. 1996. Sugar accumulation in grape berries. Plant Physiology 111: 275-283.

Deloire, A.; Carbonneau, A.; Wang, Z.; Ojeda, H. 2004. Vine and water: a short review. Journal International des Sciences de la Vigne et du Vin 38: 1-13.

Fereres, E.; Soriano, M.A. 2007. Deficit irrigation for reducing agricultural water use. Journal of Experimental Botany 58: 147159.

Haselgrove, L.; Botting, D.; Van Heeswijck; Hoj, P.B.; Dry, P.R.; Ford, C.; Iland, P.G. 2000. Canopy microclimate and berry composition: the effect of bunch exposure on the phenolic composition of Vitis vinifera L. cv. Shiraz grape berries. Australian Journal of Grape and Wine Research 6: 141-149.

Hubbard, R.M.; Ryan, M.G.; Stiller, V.; Sperry, J.S. 2001. Stomatal conductance and photosynthesis vary linearly with plant hydraulic conductance in ponderosa pine. Plant, Cell and Environment 24: 113-121.

Jackson, D.I.; Lombard, P.B. 1993. Environmental and management practices affecting grape composition and wine quality: a review. American Journal of Enology and Viticulture 44: 409-430.

Kliewer, W.M.; Dokoozlian, N.K. 2005. Leaf area/crop weight ratios of grapevines: influence on fruit composition and wine quality. Australian Journal of Enology and Viticulture 56: 170181.

Lovisolo, C.; Schubert, A.; Sorce, C. 2002. Are xylem radial development and hydraulic conductivity in downwardlygrowing grapevine shoots influenced by perturbed auxin metabolism? New Phytologist 156: 65-74.

Naor, A.; Gal, Y.; Bravdo, B. 1997. Crop load affects assimilation rate, stomatal conductance, stem water potential and water relations of field-grown Sauvignon blanc grapevines. Journal of Experimental Botany 48: 1675-1680.

Ojeda, H.; Deloire, A.; Carbonneau, U.A. 2001. Influence of water deficits on grape berry growth. Vitis 40: 141-145.

Regina, M.A.; Pereira, G.E.; Cançado, G.M.A.; Rodrigues, D.J. 2000. Calculate of the leaf area on grapevine through nondestructive method. Revista Brasileira de Fruticultura 22: 310313. (in Portuguese, with abstract in English)

Reynolds, A.G.; Wardle, D.A.; Cliff, M.A.; King, M. 2004. Impact of training system and vine spacing on vine performance, berry composition, and wine sensory: attributes of seyval and chance. American Journal of Enology and Viticulture 55: 84-95.

Ruffner, H.P. 1982. Metabolism of tartaric and malic acids in Vitis: a review; Part B. Vitis 21: 346-358.

Ruffner, H.P.; Hürlimann, M.; Skrivan, R. 1995. Soluble invertase from grape berries: purification, deglycosylation and antibody specificity. Plant Physiology and Biochemistry 33: 25-31.

Santos, T.P.; Lopes, C.M.; Rodrigues, M.L.; Souza, C.R.; Silva, J.M.R.; Maroco, J.P.; Pereira, J.S.; Chaves, M.M. 2005. Effects of partial rootzone drying irrigation on cluster microclimate and fruit composition of field-grown Castelão grapevines. Vitis 44: 117-125.

Schubert, A.; Lovisolo, C.; Peterlunger, E. 1999. Shoot orientation affects vessel size, shoot hydraulic conductivity, and shoot growth rate in Vitis vinifera L. Plant, Cell and Environment 22: 197-294.

Schultz, H.R. 2003. Differences in hydraulic architecture account for near-isohydric and anisohydric behaviour of two field-grown Vitis vinifera L. cultivars during drought. Plant, Cell and Environment 26: 1383-1405. 
Smart, D.R.; Breazeale, A.; Zufferey, V. 2006. Physiological changes in plant hydraulics induced by partial root removal of irrigated grapevine (Vitis vinifera cv.Syrah). American Journal of Enology and Viticulture 57: 201-209.

Smart, R. 1985. Principles of grapevine canopy microclimate manipulation with implications for yield and quality: a review. American Journal of Enology and Viticulture 36: 230-239.

Smart, R.; Robinson, M. 1991. Sunlight Into Wine: A Handbook for Winegrape Canopy Management. Ministry of Agriculture and Fisheries, Wellington, New Zealand.

Souza, C.R.; Maroco, J.P.; Santos, T.P.; Rodrigues, M.L.; Lopes, C.M.; Pereira, J.S.; Chaves, M.M. 2005a. Grape berry metabolism in field-grown grapevines exposed to different irrigation strategies. Vitis 44: 103-109.

Souza, C.R.; Maroco, J.P.; Santos, T.P.; Rodrigues, M.L.; Lopes, C.M.; Pereira, J.S.; Chaves, M.M. 2005b. Control of stomatal aperture and carbon uptake by deficit irrigation in two grapevines cultivars. Agriculture, Ecosystems and Environment 106: $261-274$.
Tonietto, J.; Vianello, R.L.; Regina, M.A. 2006. Macroclimatic caracterization and enological potential of different regions with viticultural aptitude in Minas Gerais. Informe Agropecuário 27: 2-55 (in Portuguese).

Williams, L.E. 1996. Grape. p.851-880. In: Zamski, E.; Schaffer, A.A, eds. Photoassimilate distribution in plants and crops: source-sink relationships. Marcel Dekker, New York, NY, USA.

Received December 19, 2008

Accepted January 08, 2010 